\title{
Nematodes (Mermithidae) parasitizing grasshoppers (Orthoptera: Acrididae) in the Pampean region, Argentina
}

\author{
J. M. Rusconi ${ }^{a}$, N. B. Camino ${ }^{a *}$ and M. F. Achinelly ${ }^{a}$ \\ ${ }^{a}$ Consejo Nacional de Investigaciones, Científicas y Técnicas - CONICET, Laboratorio de Entomonematodes, \\ Centros Científicos Tecnológicos - CCT, Centro de Estudios Parasitológicos y de Vectores - CEPAVE, \\ Universidad Nacional de La Plata - UNLP, Calle 60 y 121, s/n, La Plata, Buenos Aires, Argentina \\ *e-mail: nemainst@cepave.edu.ar
}

Received: April 9, 2015 - Accepted: October 26, 2015 - Distributed: February 28, 2017

(With 1 figure)

\begin{abstract}
This work provides the results of a survey of entomonematodes parasites of grasshoppers in grasslands of the Pampean Region, Argentina. Nymphs of Staurorhectus longicornis Giglio-Tos, Laplatacris dispar Rhen, 1939, Dichroplus elongatus Giglio-Tos, 1894 and Metaleptea brevicornis (L.) (Orthoptera: Acrididae) were collected. Mermithidae was the only family registered with seven species: Agamermis decaudata Cobb, Steiner and Christie, 1923, Amphimermis bonaerensis Miralles and Camino, 1983, Amphimermis dichroplusi Camino and Lange, 1997, Amphimermis ronderosi Camino and Lange, 1997, Hexamermis coclhearius Stock and Camino, 1992, Hexamermis ovistriata Stock and Camino, 1992, and Longimermis acridophila Camino and Stock, 1989. The values of parasitism ranged between 1-12\%, and intensity not overcome the number of 5.0 nematodes per larva. The nematodes observed showed specificity, not registering the same species of parasite in more than one host species. The Pampean region constituted an area with high diversity of mermithids where new species could be consider as bioregulator agents of this troublesome insect pests in agricultural areas of Argentina.
\end{abstract}

Keywords: nematodes, Acrididae, pest, agriculture, Argentina.

\section{Nematóides (Mermithidae) parasitando gafanhotos (Orthoptera: Acrididae) nos Pampas região, a Argentina}

\section{Resumo}

Este trabalho apresenta os resultados de uma pesquisa entomonematode parasitando gafanhotos em pastagens da região pampeana, Argentina. Ninfas de Staurorhectus longicornis Giglio-Tos, Laplatacris dispar Rhen de 1939, Dichroplus elongatus Giglio-Tos, 1894 e Metaleptea brevicornis (L.) (Orthoptera: Acrididae) foram coletados. Mermithidae era a única família registrado com sete espécies: Agamermis decaudata Cobb, Steiner and Christie, 1923, Amphimermis bonaerensis Miralles and Camino, 1983, Amphimermis dichroplusi Camino and Lange, 1997, Amphimermis ronderosi Camino and Lange, 1997, Hexamermis coclhearius Stock and Camino, 1992, Hexamermis ovistriata Stock and Camino, 1992, e Longimermis acridophila Camino and imagem, de 1989. Os valores de parasitismo variou entre 1-12\%, e intensidade não superar o número de 5,0 nematóides por larva. Os nemátodos observados demonstraram especificidade, não registar as mesmas espécies de parasita em mais do que uma espécie de hospedeiro. A região pampeana constituída uma área com alta diversidade de mermithids onde novas espécies poderiam ser consideradas como agentes bio-reguladores deste incômodos insetos pragas em áreas agrícolas da Argentina.

Palavras-chave: nematóides, Acrididae, praga, agricultura, Argentina.

\section{Introduction}

Grasshoppers are a serious group of insects causing considerable problems in crop soils. Since they are both phytophagous and polyphagous, their feeding preferences often encompass entire plant families (Almeida and Câmara, 2008).

In Argentina, the Pampean region is an important area where farming is developed and products are obtained for both domestic consumption and for export. However, grasshoppers constitute an important variable in the farming economy of this region. This pest often exhibit "Outbreaks" significant magnitude, causing considerable damage to rangelands, pastures implanted and various crops (maize, soybean, sunflower, barley, sorghum) generating substantial economic losses (Cigliano et al., 
2000, 2002; De Wysiecki et al., 2000; Lange et al., 2005; Mariottini et al., 2012).

The growing interest in environmental quality has encouraged in recent years the search for new tools to control insects of agricultural importance of health and safer and compatible with the environment.

Entomonematodes are one of the highly influential agents regulating the population dynamics of insect pests through association with their hosts in relationships ranging from fortuitous to parasitic. Many investigators have recognized these parasites as potential biological control agents (Poulin, 2012). Results showed that are a safe and effective environmental alternative for controlling pests in crops of economic importance (Duncan et al., 2013; Gumus et al., 2015; Shapiro-Ilan et al., 2010).

The knowledge of parasitic nematodes on acridids in Argentina is limited with studies of the taxonomy and biology of certain species (Camino and Stock, 1989; Camino and Lange, 1997; Miralles and Camino, 1983). In this study we present the results of a survey of entomonematodes parasites of grasshoppers in grasslands of the Pampean region, Argentina.

\section{Material and Methods}

The study was carried in grasslands of the Pampean Region, Buenos Aires province, Argentina. Samples were taken during the 2005-2010 years, from October to April (spring and summer seasons), in Brandsen ( $35^{\circ} 10^{\prime} 18^{\prime \prime} \mathrm{S}$, $\left.58^{\circ} 13^{\prime} 48^{\prime \prime} \mathrm{W}\right)$, Berazategui ( $\left.34^{\circ} 45^{\prime} 43.67^{\prime \prime} \mathrm{S}, 58^{\circ} 12^{\prime} 26.02^{\prime \prime} \mathrm{W}\right)$, and Olavarría ( $36^{\circ} 53^{\prime} 57.12^{\prime \prime} \mathrm{S}$; $60^{\circ} 19^{\prime} 24^{\prime \prime} \mathrm{W}$ ) cities (see Figure 1). Insects were collected with an entomological net of $40 \mathrm{~cm}$ in diameter and $75 \mathrm{~cm}$ deep, through 200 strokes along four transects of about $3 \mathrm{~m}$ wide and $50 \mathrm{~m}$ long each. Each strike involved a $180^{\circ}$ an arc through the vegetation. This proven methodology was to obtain representative samples of a community (Mariottini et al., 2012). Then, they were individually transported to the laboratory and maintained in plastic containers with wire-screened walls $(15 \times 10 \mathrm{~cm})$ with $100 \mathrm{cc}$ of sterilized moistened sand to emergence of mermithid nematodes (post-parasitic juveniles) from grasshoppers. Insects were maintained under these conditions for three weeks and then were dissected to determine the presence of other families of entomonematodes. Specimens that died before that period were also prospected. Identification of grasshoppers was made by Dr. C. Lange at the Center of Parasitological Studies and Vectors (CEPAVE).

Nematodes were transferred to a fixative of $50 \%$ $(\mathrm{v} / \mathrm{v})$ aqueous triethanolamine formalin, for $48 \mathrm{~h}$ and then placed in $100 \%$ triethanolamine formalin before transfer to glycerol for slow evaporation in order to clear the parasites (Seinhorst, 1959). The fixed specimens were used for taxonomic identification following the key of Poinar Junior (1977).

The following indices were calculated: parasitism percentage as the number of infected insects over the number of examined; intensity: the mean number of

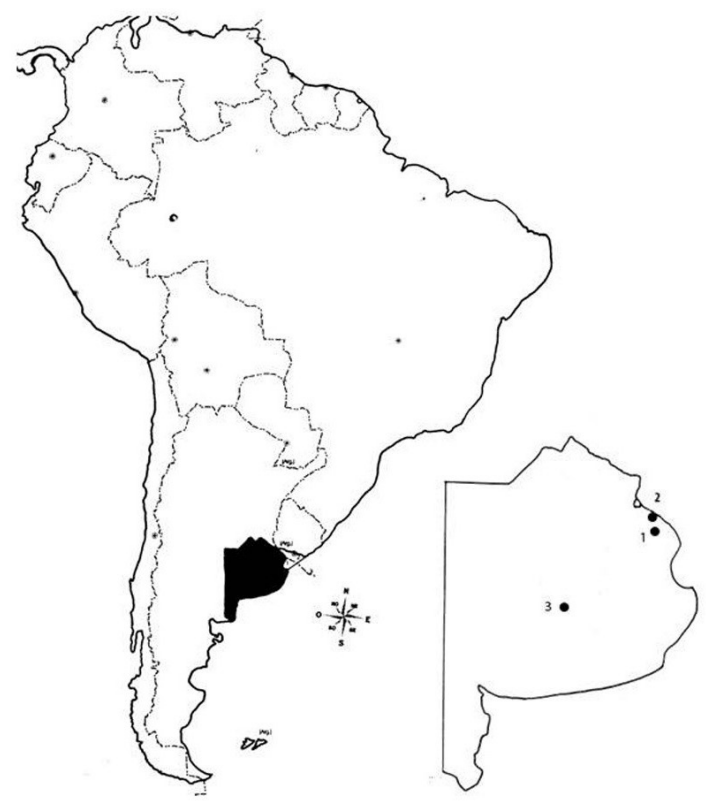

Figure 1. Map of South America and Buenos Aires province, Argentine (left) and detail map of the area sampled (right). References: 1. Brandsen; 2. Berazategui; 3. Olavarria.

emerged nematodes over the total number of parasitized insects for the same nematode species and abundance: the mean number of emerged nematodes for each species from insect over the total of examined hosts (Bush et al., 1997).

\section{Results and Discussion}

Nymphs of Staurorhectus longicornis Giglio-Tos ( $\mathrm{n}=225)$, Laplatacris dispar Rhen, 1939 (n=346), Dichroplus elongatus Giglio-Tos, 1894 ( $\mathrm{n}=358)$ and Metaleptea brevicornis (L.) $(n=251)$ (Orthoptera: Acrididae) were collected from the Pampean region. Seven mermithid species were registered at the three locations: Agamermis decaudata Cobb, Steiner and Christie, 1923, Amphimermis bonaerensis Miralles and Camino, 1983, Amphimermis dichroplusi Camino and Lange, 1997, Amphimermis ronderosi Camino and Lange, 1997, Hexamermis ovistriata Stock and Camino, 1992; Hexamermis coclhearius Stock and Camino, 1992 and Longimermis acridophila Camino and Stock, 1989 (as shown in Table 1).

The percentage of parasitism ranged from 1 to $12 \%$, the number of nematodes per insect between 2.6 to 5.0 and the mean abundance from 0.04 to 0.33 . The nematodes presented specificity, not registering the same species of parasite in more than one host species. However, grasshoppers were parasitized by more than one species in L. dispar (3) and D. elongatus (2) (as shown in Table 1). The considerable increase of the dimensions of mermithid nematodes during their development inside the host could explain the low levels of intensity observed. The maximum 
intensity (5) was recorded for Amphimermis bonaerensis in L. dispar (as shown in Table 2).

In our study, Mermithidae was the only family of nematodes isolated from the body cavity of acridids being always lethal for their hosts. Previous studies realized in wheat crops of the Pampean region, Argentina, showed a lower diversity of mermithids with a record of two species parasitizing Orthoptera (Gryllotalpidae and Gryllidae) and white grubs (Coleoptera: Scarabaeidae) (Camino and Achinelly, 2011; Camino at al. 2014).

Spirurida and Mermithidae were mentioned by Poinar Junior (1975) as the only nematode families cited in grasshoppers. This could be related with the biology parasite/host. The adults of the Order Spirurida occur in the digestive tract of definitive vertebrate hosts, requiring an

Table 1. Mermithids parasites of grasshoppers from the Pampean region.

\begin{tabular}{|c|c|c|}
\hline $\begin{array}{l}\text { NEMATODE } \\
\text { SPECIES }\end{array}$ & HOST SPECIES & LOCATION \\
\hline $\begin{array}{l}\text { Agamermis } \\
\text { decaudata }\end{array}$ & Laplatacris dispar & Brandsen \\
\hline $\begin{array}{l}\text { Amphimermis } \\
\text { bonaerensis }\end{array}$ & Laplatacris dispar & Berazategui \\
\hline $\begin{array}{l}\text { Amphimermis } \\
\text { dichroplusi }\end{array}$ & $\begin{array}{l}\text { Dichroplus } \\
\text { elongatus }\end{array}$ & Olavarría \\
\hline $\begin{array}{l}\text { Amphimermis } \\
\text { ronderosi }\end{array}$ & $\begin{array}{l}\text { Metaleptera } \\
\text { brevicornis }\end{array}$ & Brandsen \\
\hline $\begin{array}{l}\text { Hexamermis } \\
\text { coclhearius }\end{array}$ & $\begin{array}{l}\text { Dichroplus } \\
\text { elongatus }\end{array}$ & Brandsen \\
\hline $\begin{array}{l}\text { Hexamermis } \\
\text { ovistriata }\end{array}$ & $\begin{array}{l}\text { Staurorhectus } \\
\text { longicornis }\end{array}$ & Brandsen \\
\hline $\begin{array}{l}\text { Longimermis } \\
\text { acridophila }\end{array}$ & Laplatacris dispar & Brandsen \\
\hline
\end{tabular}

invertebrate intermediate host to complete their development. Mermithids can easily enter grasshoppers, showing a remarkable degree of parasite-host synchronization (Baker, 1986). Females can migrate from the soil onto the vegetation and there lay eggs during periods of high moisture. Those eggs, later consumed by the locusts along with the vegetal material hatch in the gut; the juveniles subsequently pass through the gut wall into the hemocoel and increase considerably in size inside the host. Nematodes kill the host with their emergence to the soil where they molt into the adult stage to complete the cycle (Poinar Junior, 1979).

Mermithids have been observed infecting orthopterans with high levels of infection and mortality (Mongkolkiti and Hosford, 1971; Webster and Thong, 1984). A major disturbance in the host metabolism are manifest by host tissue degeneration and retarded development, resorption and suppression of oocyte and the testes, and degeneration of the thoracic muscles reducing the flight ability in the adult hosts (Baker, 1986). Most of the mermithid species constitute a significant regulatory influence on the population dynamics of plague insects. Studies reported that mermithid nematodes can control insect populations (Baker and Capinera, 1997; Poinar Junior, 1979). In this way, Baker (1986) observed that parasites of locusts and grasshoppers in New South Wales were totally dependent on the availability of hosts for survival. If host number was low, parasite numbers was even lower. An increase in host number may provide an unlimited number of insects. So they can produce major epidemics when the infections cause the sharp decline in the population in a short term.

We can conclude that the Pampean region from Argentina is an area with high diversity of mermithid nematodes for grasshoppers. Further studies on the life cycle, longevity, seasonality and host-parasite dynamics should be applied to determine whether the density of nematode populations

Table 2. Grasshoppers parasitized by mermithids in the Pampean region, Argentina. Prevalence (P), Mean number of nematodes per infected host, intensity (I), Mean abundance (A), total number of parasites per host (N).

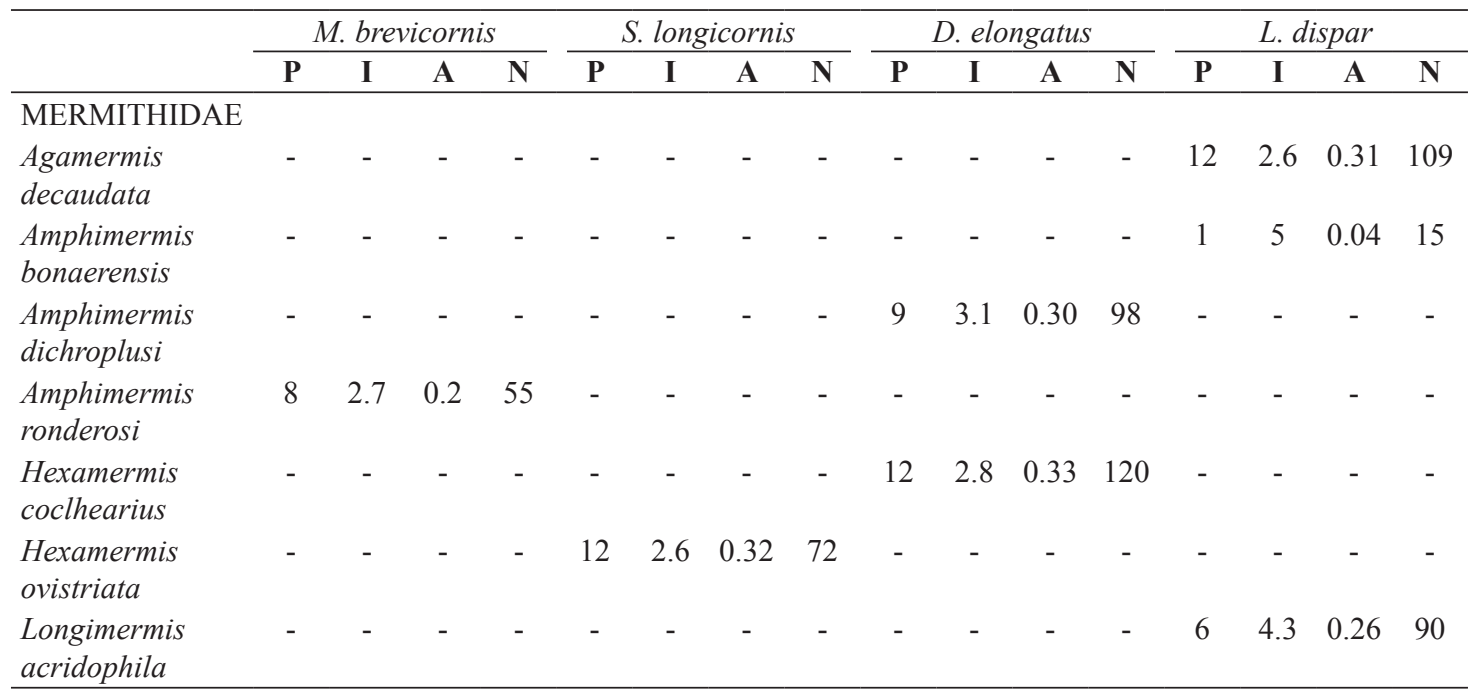


registered in our study, are depending on the availability of their hosts, being able to regulate the populations of these pest insects.

\section{Acknowledgements}

This study was partially supported by Consejo Nacional de Investigaciones Científicas y Técnicas (CONICET), Universidad Nacional de La Plata, (UNLP), and Comisión de Investigaciones Científicas de la provincia de Buenos Aires (CIC), Argentina.

\section{References}

ALMEIDA, A.V. and CÂMARA, C.A., 2008. Distribution of grasshoppers (Othoptera: Acridoidea) in the Tapacurá ecological station (São Lourenço da Mata, PE/Brazil). Brazilian Journal of Biology $=$ Revista Brasileira de Biologia, vol. 68, no. 1, pp. 21-24. http://dx.doi.org/10.1590/S1519-69842008000100004. PMid:18470374.

BAKER, G.L. and CAPINERA, J.L., 1997. Nematodes and nematomorphs as control agents of grasshoppers and locusts. Memoirs of the Entomological Society of Canada, vol. 171, pp. 157-211. http://dx.doi.org/10.4039/entm129171157-1.

BAKER, G.L., 1986. The ecology of mermithid nematode parasites of grasshoppers and locusts in south-eastern Australia. In: R.A. Samson, F.M. Vlak and D. Peters. Fundamental and applied aspects of invertebrate pathology. Wageningen: Foundation of the Fourth International Colloquium of Invertebrate Pathology, pp. 277-280.

BUSH, A.O., LAFFERTY, K.D., LOTZ, J.M. and SHOSTAK, A.W., 1997. Parasitology meets ecology on its own terms: Margolis et al. revisited. Journal of Parasitology, vol. 83, pp. 575-583.

CAMINO, N.B. and ACHINELLY, M.F., 2011. Biodiversity of insect-parasitic nematodes in soil pest insect (Orthoptera, Gryllidae and Gryllotalpidae) in wheat fields of Buenos Aires, Argentina. Annals of Biology, vol. 33, no. 15, pp. 15-21.

CAMINO, N.B. and LANGE, C.E., 1997. Two new species of the genus Amphimermis Kaburaki and Imamura (Nematoda:Mermithidae) from argentine grasshoppers (Orthoptera:Acrididae). Fundamental and Applied Nematology, vol. 20, pp. 239-242.

CAMINO, N.B. and STOCK, S.P., 1989. Un nuevo nemátodo parásito del acrídido Laplatacris dispar Rhen, 1939, en Argentina. Revista Peruana de Entomología, vol. 32, pp. 30-32.

CAMINO, N.B., ACHINELLY, M.F., RUSCONI, J.M., ELICECHE, D.P. and SALAS, A., 2014. Biodiversity of entomonematodes parasitizing soil pest white grubs (Scarabaeidae) of Buenos Aires, Argentina. Neotropical Helminthology, vol. 8, no. 2, pp. 227-233.

CIGLIANO, M.M., DE WYSIECKI, M.L. and LANGE, C.E., 2000. Grasshopper (Orthoptera, Acrididae) species diversity in the pampas, Argentina. Diversity \& Distributions, vol. 6, no. 2, pp. 81-91. http://dx.doi.org/10.1046/j.1472-4642.2000.00077.x.

CIGLIANO, M.M., TORRUSIO, S. and DE WYSIECKI, M.L., 2002. Grasshopper (Orthoptera: Acrididoidea) community composition and temporal variation in The Pampas, Argentina. Journal of Orthoptera Research, vol. 11, no. 2, pp. 215-221.
http://dx.doi.org/10.1665/1082-6467(2002)011[0215:GOACC $\mathrm{A}] 2.0 . \mathrm{CO} ; 2$.

DE WYSIECKI, M.L., SÁNCHEZ, N. and RICCI, S., 2000. Grassland and shrubland grasshopper community composition in northern La Pampa province, Argentina. Journal of Orthoptera Research, vol. 9, no. 9, pp. 211-221. http://dx.doi.org/10.2307/3503649.

DUNCAN, L.W., STUART, R.J., EL-BORAI, F.E., CAMPOSHERRERA, R., PATHAK, E., GIURCANU, M. and GRAHAM, J.H., 2013. Modifying orchard planting sites conserves entomopathogenic nematodes, reduces weevil herbivory and increases citrus tree growth, survival and fruit yield. Biological Control, vol. 64, no. 1, pp. 26-36. http://dx.doi.org/10.1016/j.biocontrol.2012.09.006.

GUMUS, A., KARAGOZ, M., SHAPIRO-ILAN, D. and HAZIR, S., 2015. Novel approach to biocontrol: Release of live insect hosts pre-infected with entomopathogenic nematodes. Journal of Invertebrate Pathology, vol. 130, pp. 56-60. http://dx.doi. org/10.1016/j.jip.2015.07.002. PMid:26149819.

LANGE, C.E., CIGLIANO, M.M. and DE WYSIECKI, M.L., 2005. Los acridoideos de importancia económica en la Argentina. In: L. Barrientos Lozano and P. Almaguer, eds. Manejo integrado de la langosta centroamericana y acridoideos plaga en América Latina. Tamaulipas: Instituto Tecnológico de Ciudad Victoria, pp. 93-135.

MARIOTTINI, Y., DE WYSIECKI, M.L. and LANGE, C.E., 2012. Variación temporal de la riqueza, composición y densidad de acridios (Orthoptera: Acridoidea) en diferentes comunidades vegetales del Sur de la provincia de Buenos Aires. Revista de la Sociedad Entomológica Argentina, vol. 71, pp. 3-4.

MIRALLES, D.A. and CAMINO, N.B., 1983. Una nueva especie de Mermithidae, Amphimermis bonaerensis sp. n. (Nematoda:Enoplida). Neotrópica, vol. 29, pp. 153-156.

MONGKOLKITI, S. and HOSFORD, R.M., 1971. Biological Control of the Grasshopper Hesperotettix viridis pratensis by the Nematode Mermis nigrescens. Journal of Nematology, vol. 3, no. 4, pp. 356-363. PMid:19322391.

POINAR JUNIOR, G.O., 1975. Entomogenous nematodes: a manual and host list of insect-nematode associations. Brill: Leiden.

POINAR JUNIOR, G.O., 1979. Nematodes for biological control of insects. Boca Raton: CRC Press.

POINAR JUNIOR, G.O., 1977. CIH Key to the groups and genera of nematode parasites of invertebrates. Farnham Royal: Commonwealth Agricultural Bureaux.

POULIN, R., 2012. Evolutionary ecology of parasites. New York: Chapman \& Hall.

SEINHORST, J.W., 1959. A rapid method for the transfer of nematodes from fixative to anhydrous glycerin. Nematology, vol. 4, no. 1, pp. 67-69. http://dx.doi.org/10.1163/187529259X00381.

SHAPIRO-ILAN, D.I., COTTRELL, T.E., MIZELL, R.F. 3rd., HORTON, D.L., BEHLE, R.W. and DUNLAP, C.A., 2010. Efficacy of Steinernema carpocapsae for control of the lesser peachtree borer, Synanthedon pictipes: Improved aboveground suppression with a novel gel application. Biological Control, vol. 54, no. 1, pp. 23-28. http://dx.doi.org/10.1016/j.biocontrol.2009.11.009.

WEBSTER, J.M. and THONG, C.H.S., 1984. Nematode parasites of orthopterans. In: W.R. NICKLE, ed. Plant and insect nematodes. New York: Marcel Dekker. 